\title{
Orális candidiasis, klinikai jellegzetességei, diagnosztikája és kezelése
}

\author{
DR. GERA ISTVÁN, DR. KÖVESI GYÖRGY
}

\begin{abstract}
Candidiasis oris a leggyakoribb opportunista infekció, amelyet egy gomba, a Candia albicans okoz. Mivel a Candida albicans tagja a normális orális flórának, és gyakorisága különböző népcsoportokban $40 \%$ körül mozog, a patogenezise még mindig nem teljesen tisztázott.

Jelen közlemény célja, hogy összefoglalja e gyakori opportunista infekció potenciális lokális és szisztémás rizikófaktorait, valamint áttekintse a különböző orális klinikai manifesztációit. Számos lokális és szisztémás hajlamosító tényező ismert. Az orális candidiasis előfordulhat akár mint primer, akár secunder infekció. A gomba képes megtapadni a hámon és penetrálni a nyálkahártyát. A lokális prediszponáló faktorok elősegítik a gomba megtapadását és növekedését, míg a szisztémás tényezők negatívan hatnak a természetes vagy szerzett immunitásra, amely felelős a gomba terjedésének kontrolljában. Több klinikai manifesztációja ismert. Előfordulhat akut és krónikus formában. A legsúlyosabb formája a pseudomembranous candidiasis. Ez valódi primer infekció, amely többnyire csak súlyos immunhiányos egyénekben alakulhat ki. A krónikus forma is leggyakrabban AIDS-es betegekben fordul elő. llyenkor gyakran találkozhatunk terápiarezisztens, nagyon hosszú ideje fennálló állhártyás Candida fertőzéssel. A betegség egyéb klinikai formái közé tartozik az erythemas candidiasis, a krónikus nodularis vagy plakkos candidiasis. A leggyakoribb klinikai forma a stomatitis protetika (denture stomatitis). További Candida asszociált szájnyálkahártya betegség a cheilitis angularis és a glossitis mediana rhombica. A klinikai diagnózis a jellegzetes objektív és szubjektív klinikai tünetek alapján legtöbbször egyszerü. A Candida-infekció laboratóriumi identifikálása azonban nem egyszerű, elsősorban azért, mert a Candida tagja a normál szájflórának és így sok egészséges egyénben is kimutatható. A leggyakoribb laboratóriumi diagnosztika technikák közé tartozik a kaparékból nyert citológiai vizsgálat és a gomba tenyésztése. A betegség kezelése komplex és sokszor komoly kihívást jelent az orvos számára. Fontos, hogy feltárjuk és amennyiben lehetséges, elimináljuk a hajlamosító tényezőket. A leggyakrabban használt gombaellenes szerek a polyen és azol csoportba tartoznak. Mivel a legtöbb orális Candida-infekció csak a felszínes nyálkahártya rétegeket érinti, elsőnek lehetőleg helyi gombaellenes kezelést alkalmazzunk. Ez annál is inkább indokolt, mert nagyon sok gombaellenes készítménynek komoly mellékhatásai lehetnek.
\end{abstract}

Kulcsszavak: Candida albicans, álhártyás candidiasis, erythemás candidiasis, krónikus nodularis candidiasis, plakkos candidiasis, stomatitis protetica, candida infekcióval társuló orális léziók

\section{Bevezetés}

A Candida subpopuláció a humán szervezetben több helyen megtalálható, többnyire a normál flóra tagja. A bőrről, bélből, hüvelyből, szájból vett kenetben egészséges személyekben is jelen van. Egyes közlemények szerint a Candida albicans a normál populáció 35-40\%-ában megtalálható [1, 2]. Az orális candidiasis a szájnyálkahártya leggyakoribb opportunista infekciója. Az esetek 90\%-áért a Candida albicans gomba felel. A patogenezis pontosan még a mai napig sem teljesen tisztázott, hiszen a Candida albicans tagja a normál orális flórának, és sokan hordozzák a szájüregben anélkül, hogy valaha is manifeszt klinikai tüneteket okozna. Azonban több olyan lokális és szisztémás rizikófaktor ismert, melyek hatására a Candida albicans a saprofita állapotból parazitává válik és patológiás folyamatokat generál. A Candida albicans gyenge patogén, és komoly, valódi infekciót csak csecsemőkorban és felnőtt korban, ál- talában súlyos immunhiányos egyénekben okoz [1, 2]. Leggyakrabban csak a nyálkahártya felszínes rétegeit betegíti meg, azonban szisztémás szóródása akár halálos is lehet. Az orális candidiasis lehet primer vagy szekunder infekció eredménye.

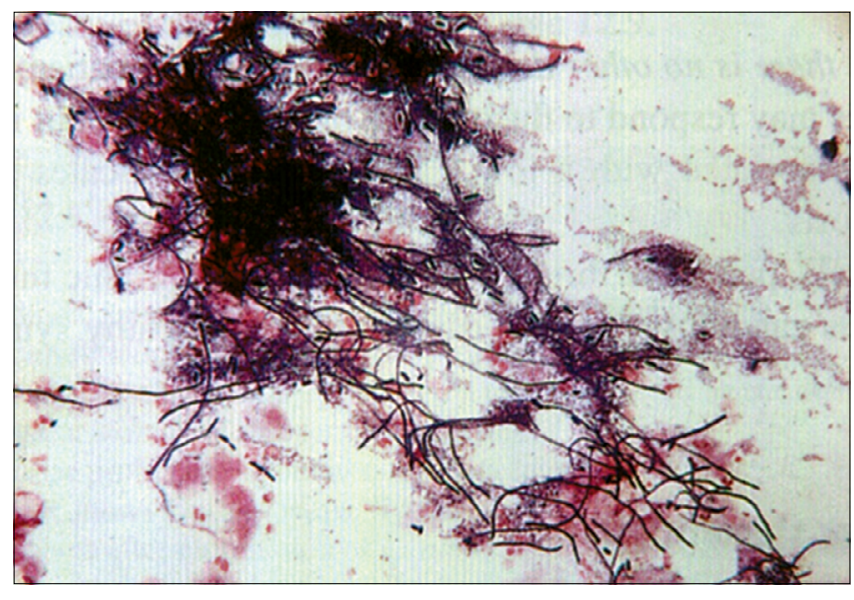

1. kép: Candia albicans mikroszkópos képe PAS festéssel 


\section{Etiopatogenezis}

Humán Candidafertózésből leggyakrabban a $C$. albicans, $C$. tropicalis és a $C$. glabrata izolálható, azonban az orális gombás fertőzések $90 \%$-áért a Candida albicans felel. A Candida élesztőgomba, amely fajspecifikusan (emberről emberre) terjed. Mikroaerophil microorganizmus (majdnem anaerob), az ATP-t glukózból, glikolízis útján nyeri [1]. Két formában lehet jelen. A fonalas forma a szaporodásra képes ún. invazív forma. A spórás forma a nyugalmi alak, de a szájban ez is okozhat elváltozást (fogsor okozta stomatitis) [3] (1. kép). Ez lehet a gomba-antigénnel szemben kifejlődő IV. típusú hypersensitivitási reakció (kontakt allergia).

A Candida albicans képes megtapadni egészséges hámsejtek felszínén, túléli a desqumatiót és behatol a nyálkahártya felszíni rétegébe is. A gombák epiteliális penetrációját elősegíti lipáze enzim aktivitása. Annak ellenére képes valódi telepet (gomba biofilm) alkotni a szájnyálkahártyán, hogy az folyamatosan lelökődik. Ebben jelentősen eltér az orális komenzális baktériumoktól, amelyek csak nem lelökődő felszíneken (fogak, korona, híd, implantátum) képeznek biofilmet [3, 4].

Nagyon szoros összefüggés van a potenciális patogén gomba jelenléte és bizonyos, ma már jól körülhatárolt lokális és szisztémás rizikófaktorok jelenléte között. Ezek járulnak hozzá manifeszt gyulladás kifejlődéséhez (1. táblázat). A lokális hajlamosító faktorok elösegítik a gomba megtapadását és növekedését, vagy gyengíthetik a nyálkahártya immun védekezését [3]. A szisztémás faktorok leggyakrabban a páciens általános immunológiai státusával vagy endokrin betegségekkel, illetve metabolikus állapotokkal (vitaminhiány, vashiány) hozhatók kapcsolatba. Erre a legjobb példa az akut pseudomembranous candidiasis, amely vagy nagyon fiatal csecsemőkben fordul elő, ahol az immunrendszer még fejletlen, vagy AIDS betegekben, ahol a celluláris immunvédelem insufficiens [5, 6]. A lokális prediszpoziciós faktorok között vezető helyen szerepel a teljes lemezes fogpótlás vagy a szájszárazság $[7,8]$.

1. táblázat

\begin{tabular}{|l|}
\hline A candidiasis oris lokális rizikótényezői \\
\hline Teljes lemezes fogpótlás \\
Dohányzás \\
Inhalációs szteroidok \\
Lokális szteroid kezelés \\
Hiperkeratozis \\
Normál orális mikroflóra egyensúly eltolódása \\
Nyálmennyiség és összetétel változás \\
\hline A candidiasis oris szisztémás rizikótényezői \\
\hline Immunhiányos állapotok \\
Immunszupresszív terápia \\
Kemoterápia \\
Súlyos legyengült fizikai állapot \\
Endokrin betegségek - diabetes \\
Vérképzőrendszer hiánybetegségei \\
\hline
\end{tabular}

\section{Epidemiológia}

Bár a Candida tagja a normál orális flórának, azonban a legtöbb epidemiológiai adat szerint az egészséges felnőtt lakosságnak csupán 35-40\%-ában mutatható ki $[2,3]$. Gyakrabban fordul elő nőkben, hospitalizált betegekben és a $O$ vércsoportba tartozók körében, akik nem hordoznak vércsoport antigéneket. Lemezes fogpótlást viselők körében az orális Candida albicans prevalencia $50 \%$-nál is magasabb [9].

\section{Klinikai formák}

Az orális Candidiasis klinikai képe változatos. Korábban két fő csoportot akut (preudomembrános és atrophias) és krónikus (atrophias és hyperplasticus) formát különítettek el. A klinikus számára jelenleg legelfogadhatóbb beosztást a (2. táblázat) mutatja [10, 11, 12].

2. táblázat

\begin{tabular}{|l|l|}
\hline Primer Orális Candidiasis & Szekunder Orális Candidiasis \\
\hline Akut & \\
\cline { 1 - 1 } $\begin{array}{l}\text { Pseudomembranosus } \\
\text { candidiasis } \\
\text { Erythaemas candidias }\end{array}$ & \\
\cline { 1 - 1 } Krónikus & \multirow{2}{*}{ AIDS } \\
\cline { 1 - 1 } $\begin{array}{l}\text { Pseudomembranosus } \\
\text { candidiasis }\end{array}$ & $\begin{array}{c}\text { Familialis mucocutan } \\
\text { Erythaemas candidias }\end{array}$ \\
$\begin{array}{l}\text { Plakkos } \\
\text { Nodularis (hyperplasticus) }\end{array}$ & $\begin{array}{c}\text { Súlyos immunhiányos } \\
\text { állapotok }\end{array}$ \\
\cline { 1 - 1 } $\begin{array}{l}\text { Candida Infekcióval Társuló } \\
\text { Orális Léziók }\end{array}$ & \\
\cline { 1 - 1 } $\begin{array}{l}\text { Stomatitis protetica } \\
\text { (denture stomatitis) } \\
\text { Cheilitis angularis } \\
\text { Glossitis mediana rhombica }\end{array}$ & \\
\hline
\end{tabular}

\section{Álhártyás candidiasis}

(Pseudomembranozus Candidiasis „szájpenész”)

Megkülönböztetünk akut és krónikus formát (2. táblázat) $[10,11,12]$. Az akut forma a primer candidiasis tipikus példája, mivel ez valóban klasszikus primer gombainfekció [13]. Az infekcióra elsősorban a csecsemők és a súlyos immunhiányos állapotban szenvedő felnőtt betegek fogékonyak [9]. Hasonlóan, iatrogen hajlamosító tényező a tartós széles spektrumú antibiotikus kezelés vagy az immunszupresszív terápia. Klinikailag az akut és krónikus forma nem különíthető el (2. kép). Ebben elsősorban az anamnézis és a beteg általános fizikális állapotának értékelése segít. Jellegzetes az álhártyaképződés, amikor a nyálkahártya felszínén valóságos gombatelepek fejlődnek ki. A álhártya a hífák hálózatából, leváló sejtekből, más mikroorganizmusokból, fibrinből és debrisből áll. Az álhártya a szövetek 


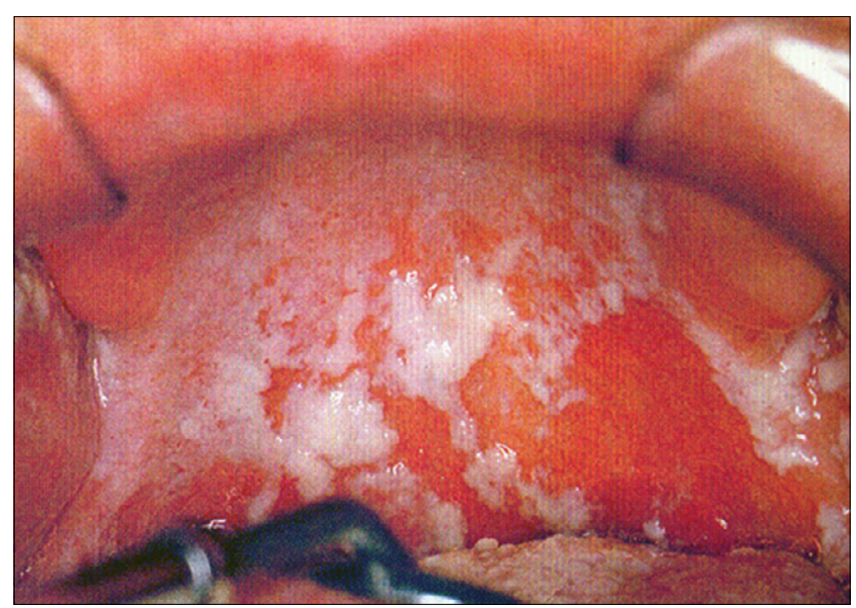

2. kép: Akut álhártyás candidiasis (soor gyep a palatumon)

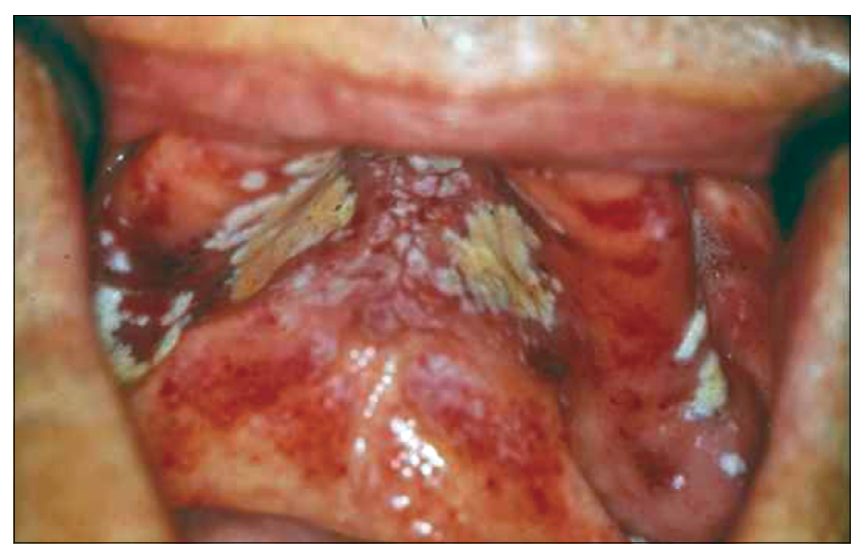

3. kép: Akut álhártyás candidiasis, az álhártya eltávolítása után vérző nyálkahártya

felszínén fekszik, de a Candida hífák mélyen behatolnak a hámba is. Ezért az álhártya eltávolítása után a nyálkahártya vérzik, mivel a gombafonalakkal együtt a felületes hám is leválik (3. kép). A száj bármely részén kialakulhat álhártyás candidiasis, gyakori a nyelven, a palátumon, de előfordulhat a garat hátsó falán is. Ez utóbbi formát komolyan kell venni, mert ráterjedhet az oesophágusra és a tracheára, szóródása akár fatális kimenetelü is lehet $[1,5]$. A krónikus forma elsősorban AIDS betegekben, vagy egyéb súlyos immunhiányos állapotban fordul elő, de előfordulhat tartósan lokális kortikoszteroid kezelés alatt álló egyénekben is. Erre jó példa tartósan orális szteroid sprayt használó asztmás betegek candidiasisa [1, 2, 3]. A krónikus álhártyás candidiasis tünetszegény, általában panaszt nem okoz a betegnek (4. kép). Azért fontos a felismerése, mert gyakran életveszélyes általános betegségek orális manifesztációja lehet.

\section{Erythaemás candidiasis}

Ez a forma lehet akut vagy krónikus a lézió fennállásának időtartamától függóen. Lehet lezajlott akut álhártyás candidiasis következménye is. Primeren a beteg- ség antibiotikum vagy szteroidkezelés következtében alakul ki. Az akut erythaemás candidiasis hasonlít a soor gyepre, de a nyálkahártyát nem fedi álhártya. Az érintett nyálkahártya terület vöröses és fájdalmas (5. kép) [1, $3,14]$. Az orális candidiasisnak ennél a formájánál valóban jelentős lehet a fájdalom, sőt a betegnek az általános közérzete is rossz. Ilyenkor a hífák csak felületesen fedik az atrófiás hámot. Ez a candidaforma gyakori immunhiányos betegeken (AIDS, leukémia, cytostaticus kezelés), de más betegeken is előfordul (pl. hosszú távú antibiotikus kezelés, tartós lokális vagy szisztémás szteroidhasználat).

\section{Hyperplasticus Candidiasis} (krónikus nodularis vagy plakkos candidiasis)

A krónikus hyperplasticus candidiasist, más néven mint candida leukoplakiát is ismerik (6. a, b kép). A Candidafertőzésnek ezt a krónikus formáját az irodalom prekancerózus állapotnak tekinti, mert elsősorban dohányosokban alakul ki. Jelenleg az irodalmi adatok szerint a Candidafertőzés következtében kialakuló malignus transzformáció incidenciája eléri a 15\%-ot [15, 16]. Klinikailag mint környezetéből kiemelkedő, egyenetlen felszínü, szabálytalan vöröses-fehéres folt jelenik meg.

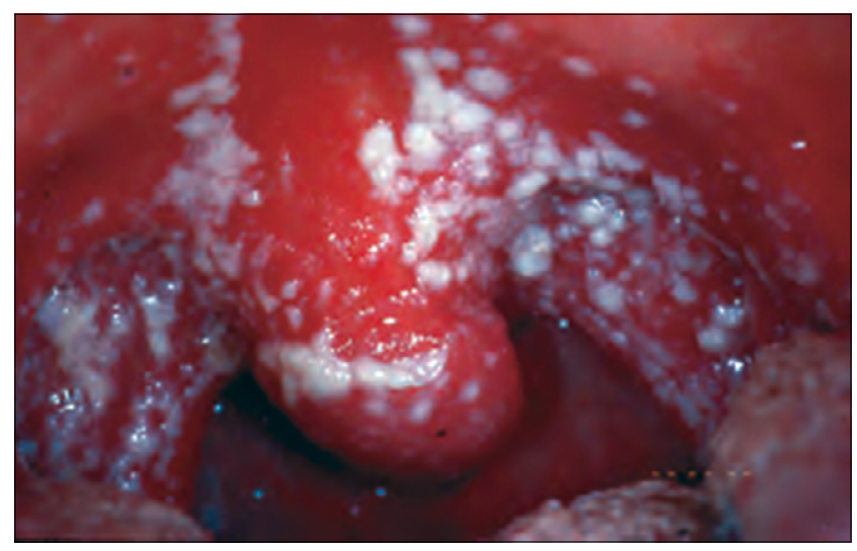

4. kép: Krónikus álhártyás candidiasis immunhiányos páciens lágy szájpadi nyálkahártyáján

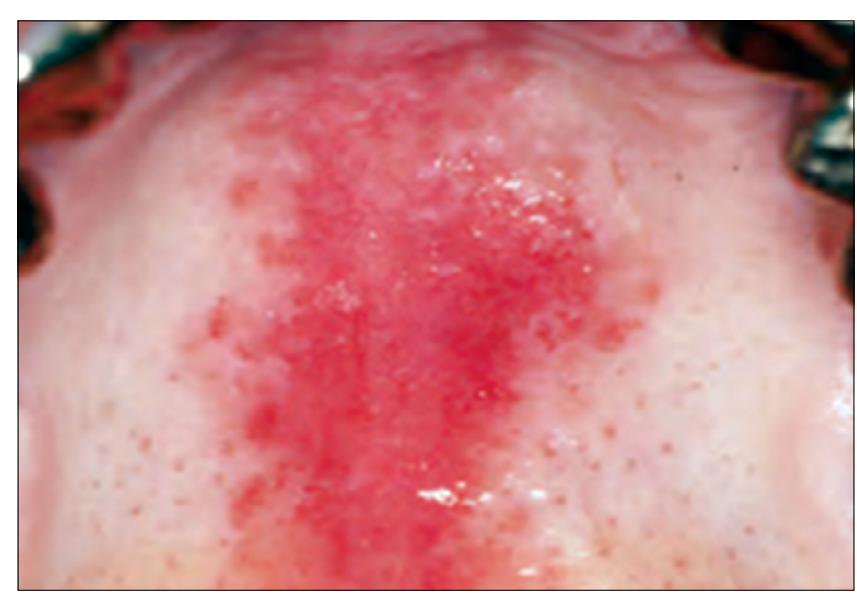

5. kép: Erythaemas candidiasis a palatumon rögzített fogpótlást viselő páciensen 

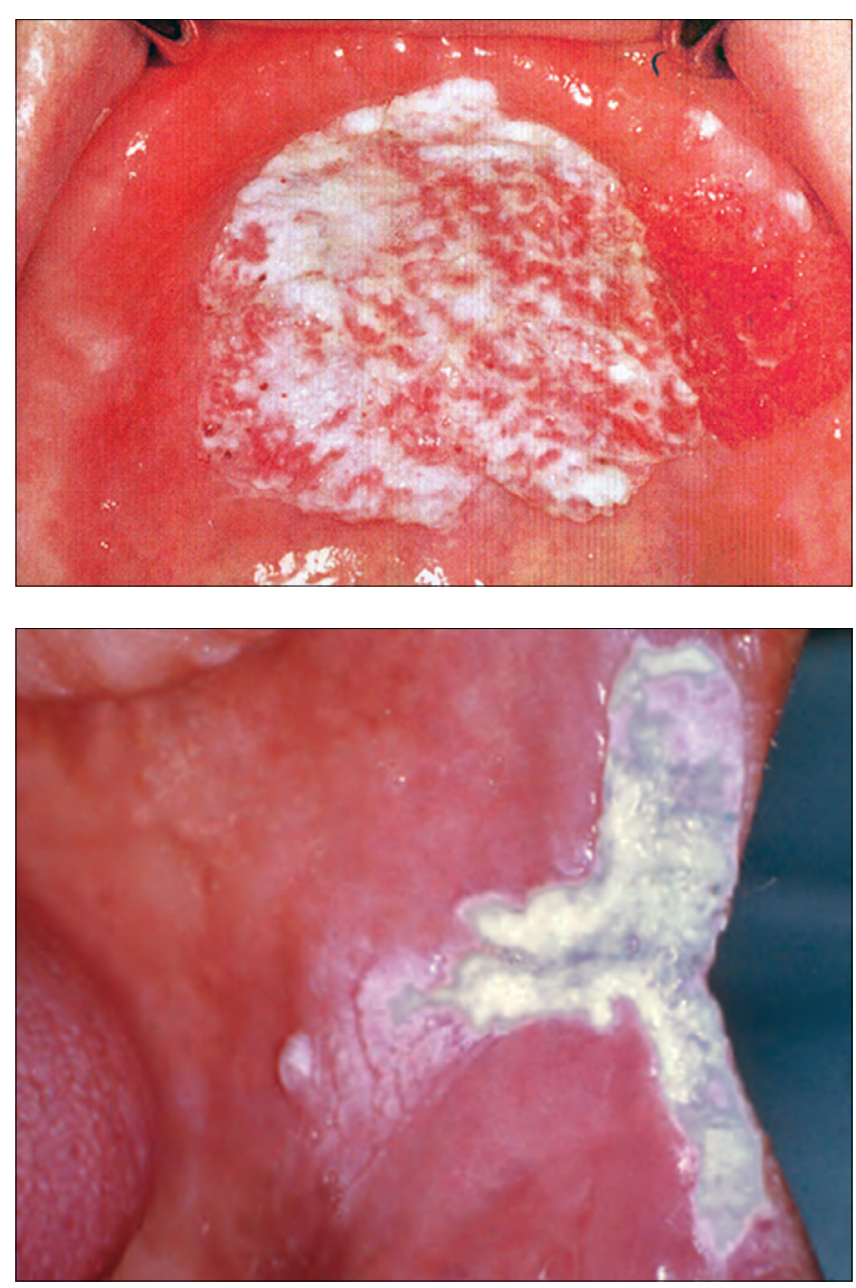

6. kép: Hyperplasticus candidais (candida leukoplakia) a) a palatumon, b) a buccan és az ajakzugban

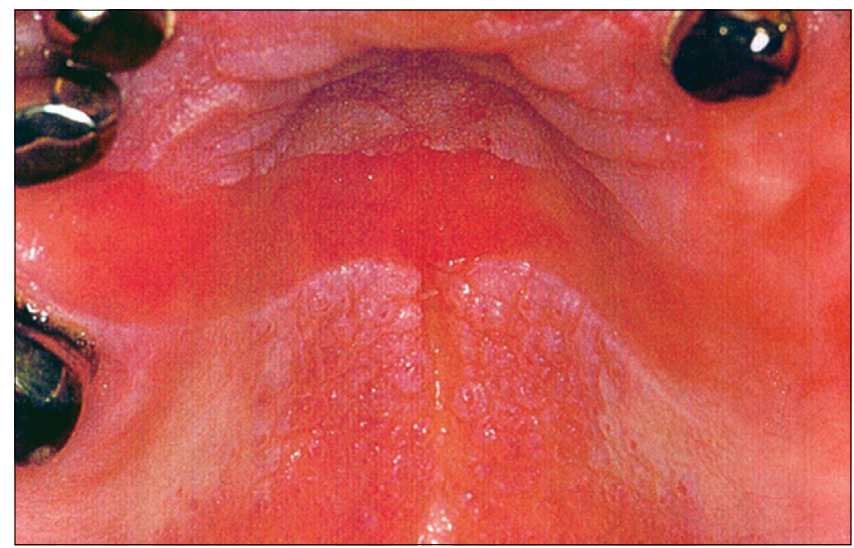

7. kép: A stomatitis protetica (denture stomatitis) tipikus képe, csak a protézis alaplemezével érintkező palatinális nyálkahártya gyulladt pontosan lemintázva az alaplemez formáját

\section{Fogsor okozta gombás szájgyulladás} (stomatitis protetica, denture stomatitis)

Az orális candidiasis leggyakoribb formája az esetek többségében fájdalmatlan. A mikroflóra komplex, a fogsor lemezzel borított szájnyálkahártyáról a Candida mel- lett több orális patogén mikroorganizmus tenyészthető ki (Streptococcus, Veillonella, Lactobacillus, Prevotella, Actinomyces). Azonban kérdéses, hogy a patogenezisben a baktériumok milyen mértékben játszanak szerepet $[1,2,3,7,8]$. Bár a fogsor rossz fekvése nem feltétele a betegség kialakulásának, a legtöbb esetben régi fogsor alatt alakul ki. A klinikai képet a felső fogsor által fedett területen a fogsor szélének megfelelően éles határral elkülönülő hyperaemia jellemzi. Az alsó fogsor alatti nyálkahártya felszínek nem érintettek (7. kép). A protézis alaplemeze a hordozó anyag, amelyben a mikroorganizmusok perzisztálnak. A kontakt allergiához hasonlóan egyértelmúen éles határral csak a fogsorral fedett területre lokalizálódik, Patomechnizmusában a spórás forma sejtmembrán antigénjeivel szemben kialakult IV-es típusú immunreakció felelhet. Abban is megegyezik a klasszikus kontakt allergiás reakcióval, hogy csak akkor szúnik meg, ha a gombát hordozó fogsort eltávolítjuk. Gyakran akrilát okozta kontakt allergiás reakcióval tévesztik össze.

A fogsor alatti gyulladt terület környezetéböl kiemelkedhet, ami szivacsszerü, granuláris szövetnek túnik, de a hámszövet nem ulcerálódott. Az elváltozást a Newton osztályozás súlyossága szerint három típusba sorolja [17]:

I. típus: lokalizált, elszórt vörös foltok, amit a protézisirritáció okoz.

II. típus: a fogsorral fedett nyálkahártya diffúz gyulladása (8. a kép).

III. típus: diffúz gyulladás, a palatum középvonalában hyperplasticus hám-papillomatosis palati (8. b, c kép).

\section{Cheilitis anguláris}

A cheilitis anguláris mint erythaemas, rhagadiform lézió jelenik meg a szájzugban [18, 19]. Elöfordul akut és krónikus változata (9. a, b kép). A Candida mellett gyakran szerepel a Staphylococcus aureus mint kóroki tényező. Rizikófaktor fogsorviselőkben a süllyedt harapási magasság, valamint vitaminhiányos (B1, B5, B12) és vashiányos állapotok. A stomatitis protetikákban szenvedők közel $40 \%$-ának van cheilitis anguláris betegsége is. Nem kezelt esetben a krónikus cheilitis angularis sokszor társul mély fissurákkal az ajakzugban (10. a, b kép).

\section{Glossitis mediana rhombica}

A glossitis mediána rhombica kialakulhat a nyelv fejlódési zavara következtében, amikor a három telepből fejődő nyelv hátsó lebenye (tuberculum impar) nem sülylyed le és nem fedi el a két laterális lebenyből fejlődő nyelv (11. kép). Ilyenkor a nyelv közepén, a foramen coecum előtt vöröses foltot vagy kiemelkedő dudort látunk. Ez nem betegség, csak fejlődési variáns. Ugyanakkor az ehhez hasonló elváltozást Candida albicans krónikus fertőzéssel kapcsolatos betegségként is osztályozzák, mivel a krónikus candidainfekció a nyelvháton a középvonalban vöröses depapillált terület okozhat, közvetlenül a papilla cirkumvalláték előtt [15, 20]. Ilyenkor az esetek 

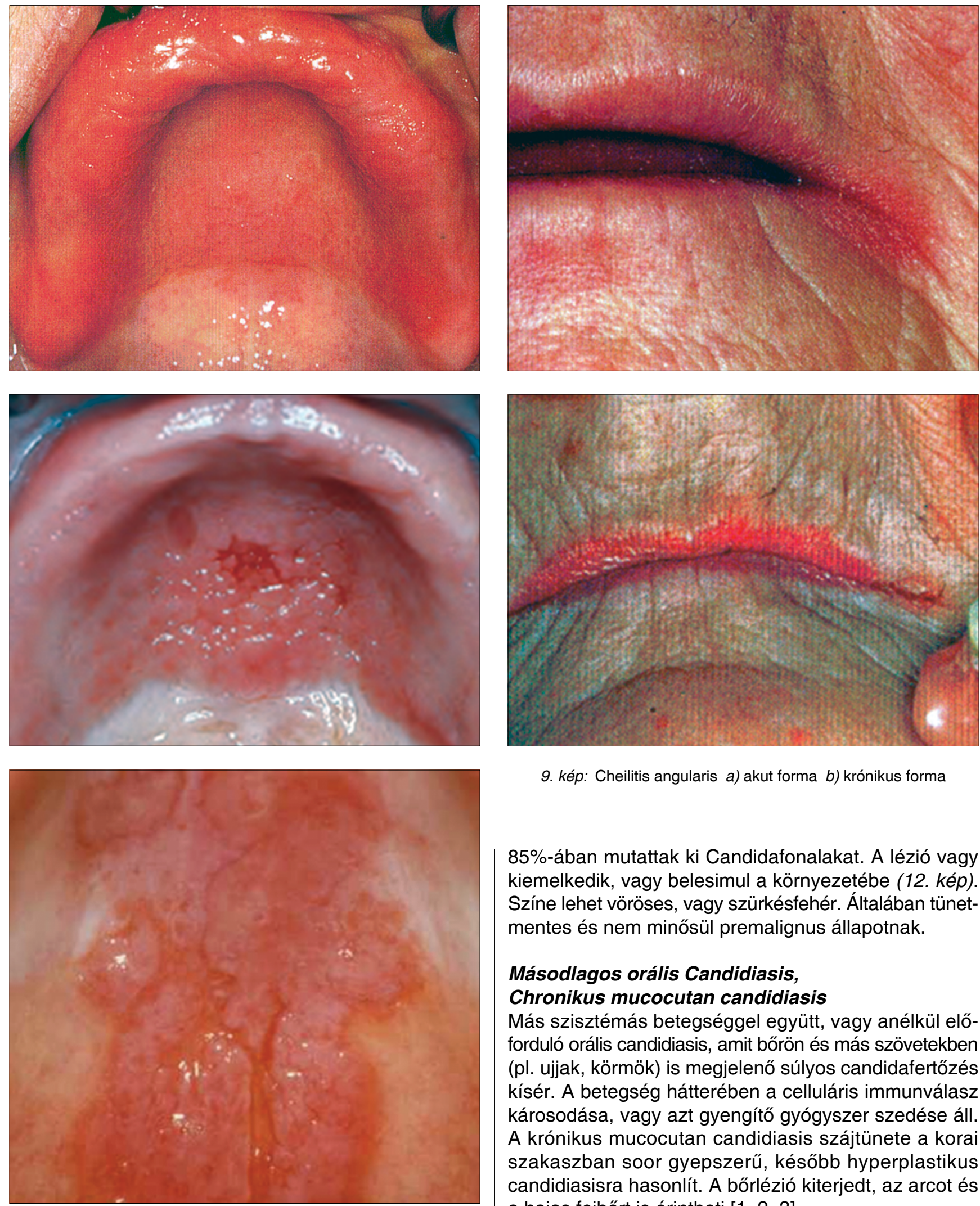

9. kép: Cheilitis angularis a) akut forma b) krónikus forma

85\%-ában mutattak ki Candidafonalakat. A lézió vagy kiemelkedik, vagy belesimul a környezetébe (12. kép). Színe lehet vöröses, vagy szürkésfehér. Általában tünetmentes és nem minősül premalignus állapotnak.

\section{Másodlagos orális Candidiasis, Chronikus mucocutan candidiasis}

Más szisztémás betegséggel együtt, vagy anélkül előforduló orális candidiasis, amit börön és más szövetekben (pl. ujjak, körmök) is megjelenő súlyos candidafertőzés kísér. $A$ betegség hátterében a celluláris immunválasz károsodása, vagy azt gyengítő gyógyszer szedése áll. A krónikus mucocutan candidiasis szájtünete a korai szakaszban soor gyepszerü, később hyperplastikus candidiasisra hasonlít. A bőrlézió kiterjedt, az arcot és a hajas fejbört is érintheti $[1,2,3]$.

8. kép: A stomatitis protetica Newton-féle osztályozása a súlyossága szerint.

a) II típus: a fogsorral fedett nyálkahártya diffúz gyulladása

b) III típus: diffúz gyulladás,

a palatum középvonalában hyperplasticus hám

c) III típus: tipikus palatinalis papillaris hyperplasia (papillomatosis palati)

\section{A HIV-infekcióval társuló orális candidiasis}

A HIV pozitív (AIDS) betegek $90 \%$-ában krónikus orális és nem orális candidiasis zajlik A leggyakoribb klinikai 


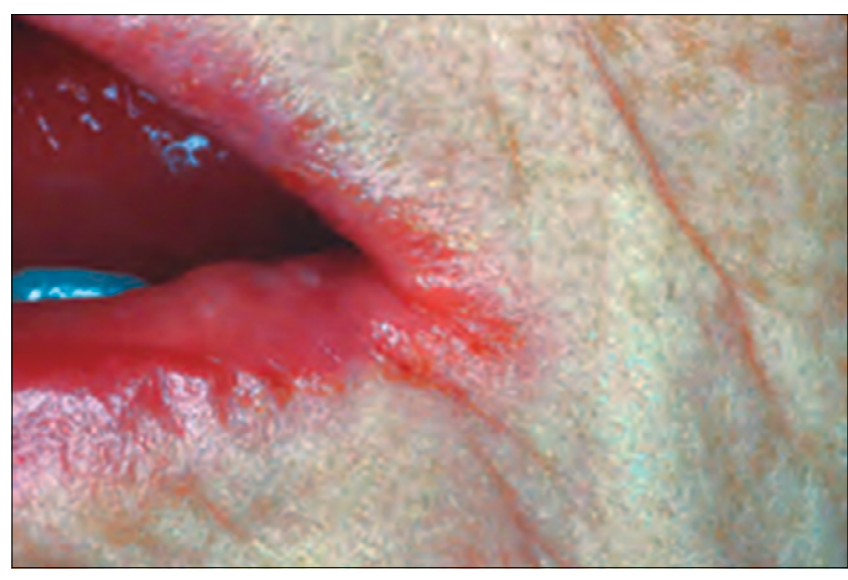

10. kép a: Nem kezelt, mély fissurákkal társuló krónikus cheilitis angularis

formák: pseudomembranous candidiasis, erythematous candidiasis, cheilitis angularis, chronicus hyperplasticus candidiasis. Sokszor társulhat chronikus mucocutan candidiasissal is. Az antiretroviralis terápia (HAART) elterjedése óta a gyakorisága csökkent [1, 2, 3, 14].

\section{Az orális candidiazis diagnózisa}

Mivel a Candida albicans tagja a normál orális flórának, ez megnehezíti a laboratóriumi diagnosztikát. Csak bizonyos szubjektív és objektív panaszokkal együtt értékelhetők a laboratóriumi eredmények. Az érintett területről vett hámsejtkaparék citológiai vizsgálata egyszerű és sokszor célravezető módszer. Az üveglapra szélesztett kaparékot izopropil alkoholos fixálás után periodic acid-Schiff (PAS) festéssel jól láthatók mind a spórák, mind a gombafonalak (1. kép) [1, 2]. Ez elsősorban álhártyás candidiasis kimutatásában nagy segítség. A szájnyálkahártyáról vett anyagot melaszos agáron (Sabouraud agar) tenyésztik $37^{\circ} \mathrm{C}$-os hőmérsékleten egy hétig. A kinőtt telepek száma diagnosztikus értékű. Emellett alkalmazható nyáltenyész-

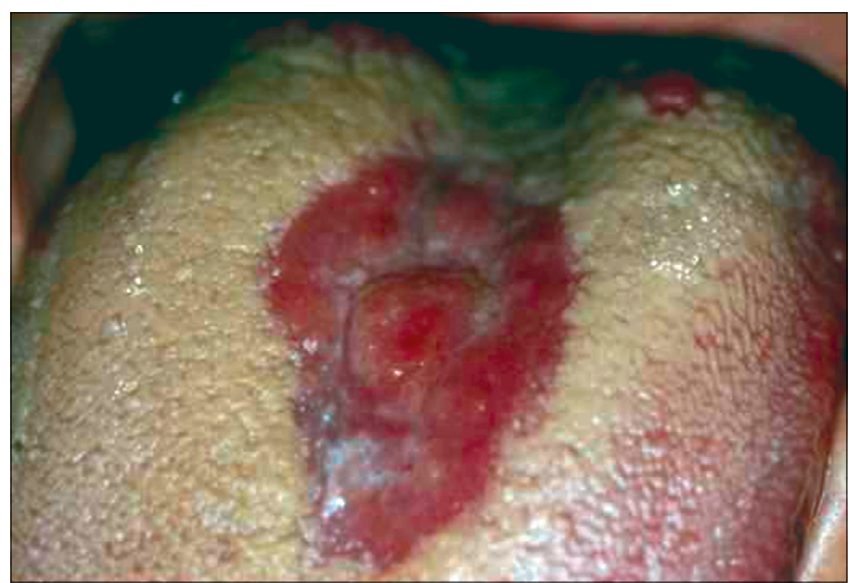

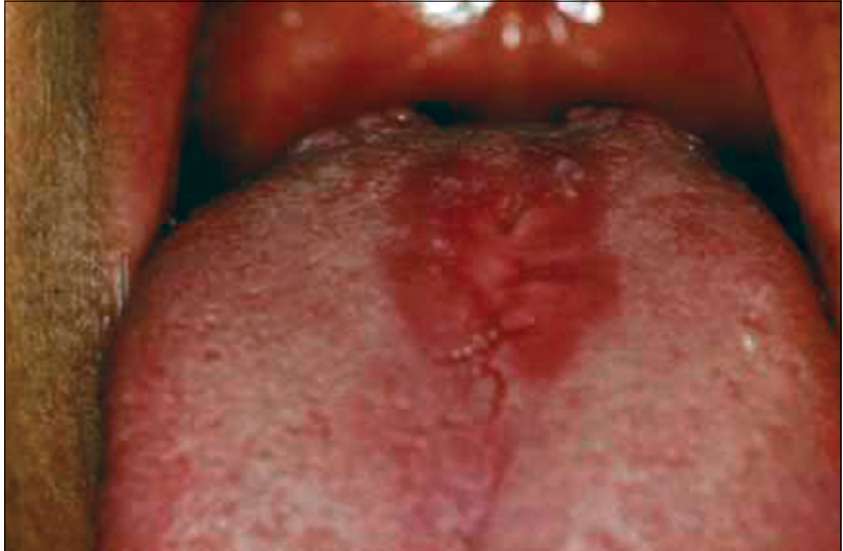

11. kép: A glossitis mediana rhombica a nyelv közepén, a foramen coecum körül vöröses depapilláalt folt

tés is. Pozitív esetben gombaszám 800 sejt/ml nyálmennyiség felett mérhető. A Candida albicans kimutatására alkalmas gyorsteszt a Mikrostix. A csíkon a vizsgáló terület bizmutot tartalmaz, melyre glukóz tartalmú folyadékot cseppentünk. A szájból vett kenetet erre a területre szélesztjük és 24 órán át $37^{\circ} \mathrm{C}$-on inkubáljuk. A glukózból képződő tejsav a bizmutot oxidálja. A bizmut oxid sötétbarna, ami látható és semiquantitatív módon értékelhető. A tenyésztési technikák mellett hyperplasticus candidiasisban (Candida leukoplakia) differenciál diagnosztikai szempontból szövettani vizsgálat is indikált. A hosszú ideje fennálló, vagy kezelés-rezisztens eseteknél a vérképet és a vércukorszintet (HbA1c) ellenőrizni kell. Indokolt esetben teljes körü immunológiai vagy endocrinológiai vizsgálatot kell végezni $[1,2]$.

\section{Terápia}

Az orális candidiasis gyógyszeres kezelése előtt fel kell tárni a hajlamosító rizikótényezőket. A lokális faktorokat lehetőség szerint eliminálni kell [1,2]. A leggyakrabban

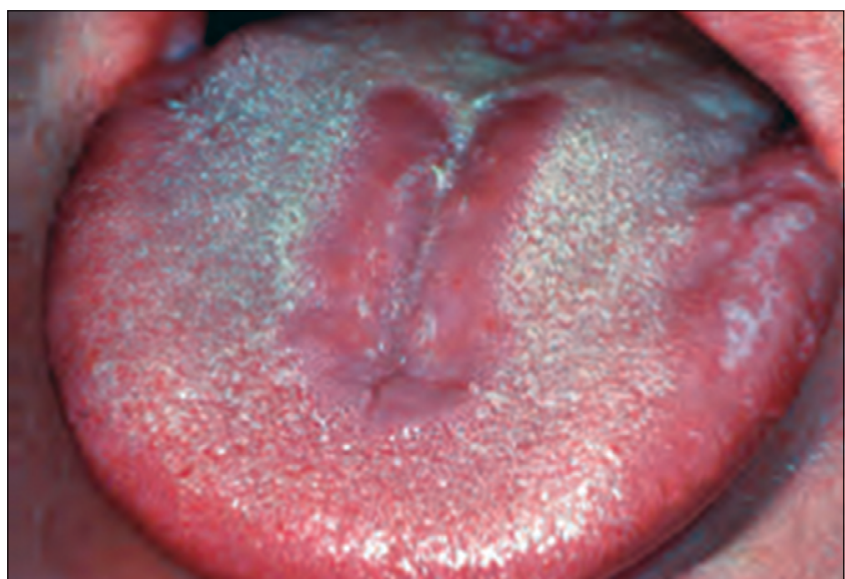

12. kép $a, b$ : A krónikus candidainfekcióval társuló glossitis mediana rhombica (median romboid glossitis) a) vagy kiemelkedik a nyelv felszínéből, b) vagy belesimul a környezetébe 
alkalmazott antifungális gyógyszerek a polyenek vagy azolok csoportjába tartoznak [21]. A polyenek (nystatin, amphotericin B) nem szívódnak fel a gastrointestinalis traktusból, ezért ideálisan alkalmazhatók lokális kezelésben [22]. A stomatitis protetica esetében el kell távolítani a régi fogsort, mert a porózus akrilát alaplemezből a gomba tökéletesen nem irtható ki, és a gomba antigén továbbra is fenntartja a gyulladást. Az új fogsor elkészültével nagyon fontos a tökéletes szájhigiénia és a fogsor rendszeres tisztítása, a ma kereskedelmi forgalomban lévő speciális fogsortisztító készítményekkel. Alkalmazható chlorhexidines szájöblítő is, de ez nagyon elszínezi a protézist és megzavarja a Nystatin hatását is. A III. típusú stomatitis protetica kezelése sebészi, kiegészítve megfelelő gombaellenes kezeléssel.

Az azol (imidazol- és triazolszármazékok) csoportba tartozó gyógyszerek (ketoconazole, flucanozol, itraconazole) esetében sokszor komoly mellékhatásokkal kell számolni [23, 24]. A ketakonazole (Nizoral) komoly májkárosító hatása miatt ma már csak lokálisan adható. Lokálisan cheiltis angularisban jó hatással alkalmazható a micozonol (Mycosol), előnye, hogy gátolja a $S$. aureus szaporodását is. A szisztémásan adható triazolszármazékok közül fluconazole (Diflucan, Fluconozol), itracdonazole (Orungal) nagyon jó hatású a súlyos gombás fertőzésekben, súlyos immunhiányos páciensek krónikus candidiasis kezelésében, valamint mélyen ülő primer candidiasisban, krónikus hyperplasticus candidiasisban és median rhomboid glossitisben. Mivel kölcsönhatásba lépnek a K-vitamin antagonista Warfarinnal, ezzel számolnunk kell anticoaguláns terápia alatt álló betegeink kezelése során [1, 2].

\section{Összefoglalás}

Az orális candidiasis a leggyakoribb opportunista infekció. A Candida albicans a legtöbb ember normál szájflórájának része, patogénné azonban csak bizonyos lokális és szisztémás hajlamosító tényezők jelenlétében válik. Több klinikai manifesztációja ismert. Sokszor tünetmentes, azonban gyakran jár szájégéssel, szájszárazsággal. Az egyik vezető oka az ún. szájégés szindrómának. Kezelése legtöbbször egyszerü, azonban néha számolni kell terápiarefrakter esetekkel, ahol a tartós lokális és szisztémás antifungális kezelés ellenére sem szúnik meg a beteg objektív vagy szubjektív panasza.

Anyagi támogatás: A közlemény megírása, illetve a kapcsolódó kutatómunka anyagi támogatásban nem részesült.

Érdekeltségek: A szerzőknek nincsenek érdekeltségeik.

\section{Irodalom}

1. Kövesı Gy (szerk.): Orális Medicina, 6. fejezet Kövesi Gy. Gombás fertőzések a szájban 43-51. Semmelweis Kiadó, 2016.

2. GLICK, M (szerk.): Burket's Oral Medicine 12th edition 2. fejezet Jontell M, Holmstrup P. Red and White Lesions of the Oral Mucosa, (77-84.) People's Medical Publishing House-USA Shelton, Connecticut, 2015.

3. Samaranayake LP, Keung Leung W, Jin L: Oral mucosal fungal infections. Periodontol 2000. 2009; 49: 39-59.

4. Olsen I: Oral Adhesion of yeasts. Acta Odontol Scand. 1990, 48: 45-49.

5. Samaranayake LP: Oral mycoses in HIV infection. Oral Surg Oral Med Oral Pathol. 1992; 73: 171-180.

6. Samaranayake LP, Holmstrup P: Oral candidiasis and human immunodeficiency virus infection. J Oral Pathol Med. 1989; 18: 554-564.

7. Hannah VE, O'donnell L, Robertson D, Ramage G: Denture Stomatitis: Causes, Cures and Prevention. Prim Dent J. 2017 Dec 1; 6. (4): 46-51.

8. Perić M, Žıvković R, Miııćlemić A, et al.: The severity of denture stomatitis as related to risk factors and different Candida spp. OralSurg Oral Med Oral Pathol Oral Radiol. 018 Mar 22. (Epub ahead of print)

9. Gendreau L, Loewy ZG: Epidemiology and etiology of denture stomatitis. J Prosthodont. 2011 Jun; 20 (4): 251-260. doi: 10.1111/j.1532-849X.2011.00698.x. Epub 2011 Apr 4. Review.

10. Holmstrup $P$, Axell T: Classification and clinical manifestation of oral yeast infections. Acta Odont Scand. 1990; 48: 57-59.

11. Axell T, Samaranayake LP, Reichart PA, Olsen I: A proposal for reclassification of oral candidosis. Oral Surg Oral Med Oral Pathol Oral Radiol Endod. 1997: 84: 111-112.

12. Mahajan B, Bagul N, Desal R, Reddy M, et al.: Pseudomembranous Type of Oral Candidiasis is Associated with Decreased Salivary Flow Rate and Secretory Immunoglobulin A Levels. Mycopathologia. 2015 Aug; 180 (1-2): 75-80.

13. WhEAT J: Endemic mycoses in AIDS: a clinical review. Clin Microbiol Rev. 1995; 8: 146-159.

14. Samaranayake LP, Holmstrup P: Oral candidiasis and human immuno-deficiency virus infection. J Oral Pathol Med. 1989; 18: 554-564.

15. Walker DM, Arendorf T: Oral candidosis. In: Samaranayake LP, MACFARLANE TW, editors. Candidial leukoplakia, chronic multifocal candidosis and median rhomboid glossitis. London: Wright, 1990: 184-199.

16. BÁNÓCZY J, SUGÁR L: Longitudinal studiess in oral leukoplakias. J Oral Pathol. 1972; 1 (6): 265-272.

17. Newton AV: Denture sore mouth. Br Dent J. 1962; 112: 357-361.

18. BudtZ-JorJenson E: Oral candidosis. In: Samaranayake LP, MacFarlane TW, editors. Candida-associated denture stomatitis and angular chielitis. London: Wright, 1990: 156-183.

19. Dias AP, Samaranayake LP: Clinical, microbiological and ultrastructural features of angular cheilitis lesions in Southern Chinese. Oral Dis. 1995; 1: 43-48.

20. Bánóczy J, Rigó O, AlbReCht M: Prevalence study of tongue lesions in a Hungarian population. Community Dent Oral Epidemiol. 1993 Aug. 21 (4): 224-226.

21. MCGINNIS MR, RINALDI MG: Antibiotics in laboratory medicine. In: Lorian V, editor. Antifungal drugs: mechanisms of action, drug resistance, susceptibility testing and asseys of activity in biological fluids. Baltimore: Williams \& Wilkins, 1996: 176-211.

22. Martin MV, Farrelly PJ, Hardy P: An investigation of the efficacy of nystatin for the treatment of chronic atrophic candidosis (denture sore mouth). Br Dent J.1986; 160: 201-204.

23. Samaranayake LP, Furguson MM: Delivery of antifungal agents to the oral cavity. Adv Drug Diliv Rev. 1994; 13: 161-179.

24. Ellepola AN, Samaranayake LP: Antimycotic agents in oral candidosis: an overview: 1. Clinical variants. Dent Update. 2000; 27: 111-112. 
Gera I., Kövesı Gy.

\section{Oral candidiasis, its clinical manifestations, diagnostics and therapy}

Oral candidiasis is the most common oral opportunistic infection caused by a yeast, Candida albicans. As Candida albicans is a member of the normal oral flora and its prevalence is around $40 \%$ among humans, the pathogenesis is still not clear.

The aims of the publication were, to make an attempt to overview the potential systemic and local risk factors of this opportunistic infection and also to summarise its clinical manifestations in the oral cavity.

Several local and systemic factors are known that can convert the saprophytic yeast to active pathogenic state. Oral candidiasis is divided into primary and secondary infections. Candida can adhere and penetrate the epithelial lining of the oral mucosa. The local predisposing factors facilitate the adherence and growth of the yeast, while systemic predisposing factors negatively affects the innate and adaptive immune system that control the growth of the yeasts. Several clinical manifestations can be distinguished. There are acute and chromic forms. The most severe form is the acute pseudomembranous candidiasis (thrush). It is a true primary infection that mostly affects severely compromised subjects. Its chronic forms mostly present in patients infected with human immunodeficiency virus (HIV). AIDS patients can be affected by a therapy resistant long term pseudomembranous Candida infection. The other clinical forms of disease are erythematous candidiasis, chronic plaque-type and nodular candidiasis. The most common clinical form is the so called denture stomatitis. Also some other Candia associated oral diseases - like median rhomboid glossitis and cheilitis angularis are recognized. The clinical diagnosis is relatively simple based on its characteristic clinical signs and subjective symptoms. The laboratory confirmation of the Candida infections is more difficult, as the Candida genus is part of the normal flora. Cytological smear techniques and culturing are the most common laboratory techniques. The disease management is complex and sometimes is really challenging. It is important to identify and if it is possible eliminate the predisposing factors. The most commonly used antifungal drugs belong to the groups of polyenes or azoles. It is because the majority of oral fungal infections affect only the superficial layers of oral mucosa the first choice of therapy should be the topical application of the antifungal drugs, because the majority of antifungal drugs have several systemic side effects.

Keywords: Candida albicans pseudomembranous candidiasis erythematous eandidiasis, ehronic plaque-type and nodular candidiasis, denture stomatitis, Candia associated oral diseases 